\title{
"The impact of smartphone advergames characteristics on purchasing intentions: the mediating role of game involvement"
}

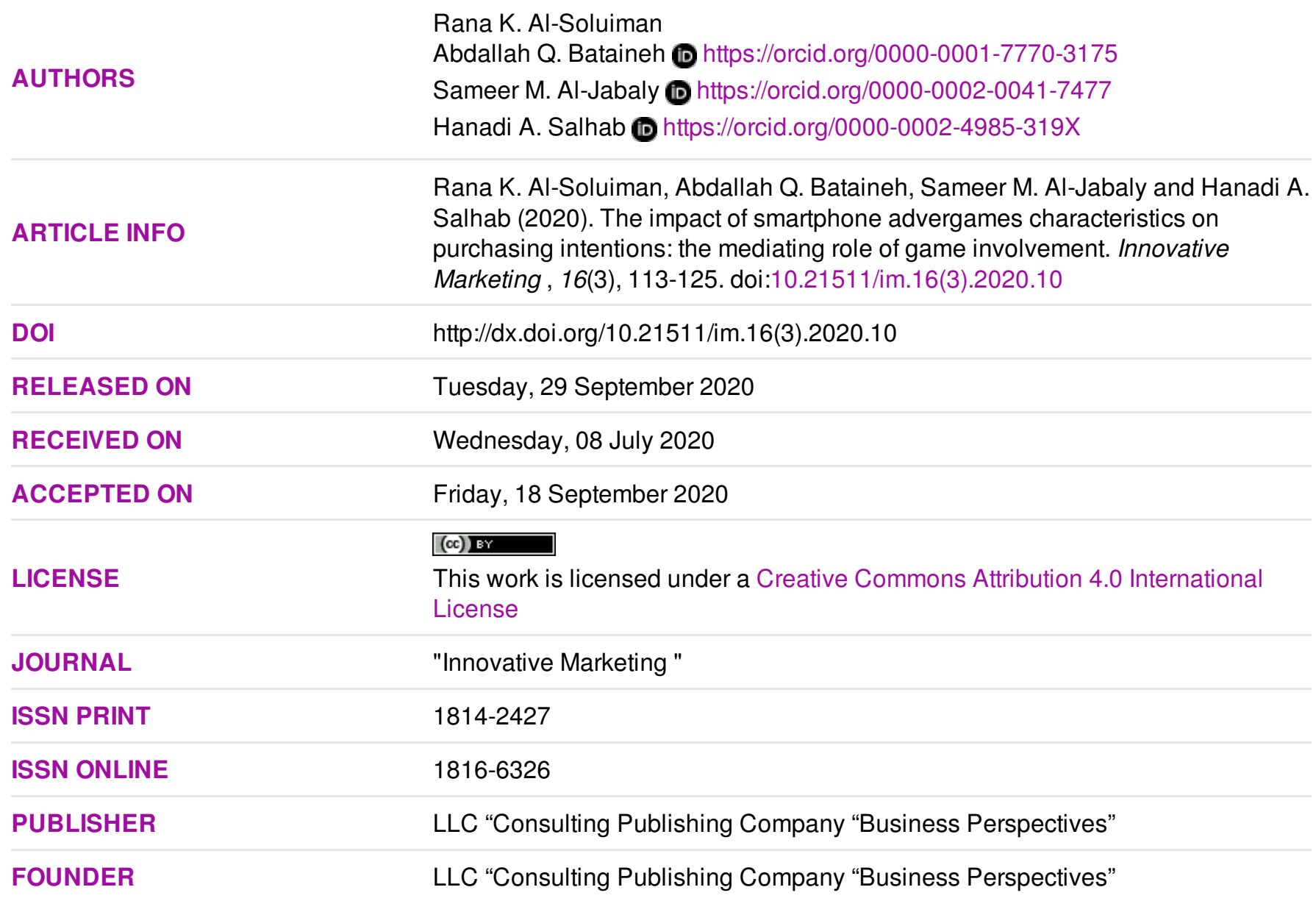

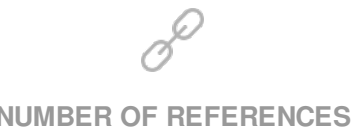

43



NUMBER OF FIGURES

1
NUMBER OF TABLES

15

(c) The author(s) 2022. This publication is an open access article. 


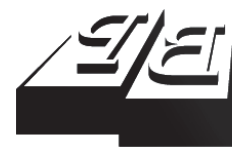

\section{BUSINESS PERSPECTIVES}

(2)

LLC "CPC "Business Perspectives"

Hryhorii Skovoroda lane, 10, Sumy, 40022, Ukraine

www.businessperspectives.org
Received on: $8^{\text {th }}$ of July, 2020 Accepted on: $18^{\text {th }}$ of September, 2020 Published on: $29^{\text {th }}$ of September, 2020

(c) Rana K. Al-Soluiman, Abdallah Q. Bataineh, Sameer M. Al-Jabaly, Hanadi A. Salhab, 2020

Rana K. Al-Soluiman, MBA Student, Faculty of Business, Marketing Department, Applied Science Private University, Jordan.

Abdallah Q. Bataineh, Associate Professor, Faculty of Business, Marketing Department, Middle East University, Jordan. (Corresponding author)

Sameer M. Al-Jabaly, Associate Professor, Faculty of Business, Marketing Department, Middle East University, Jordan.

Hanadi A. Salhab, Assistant Professor Faculty of Business, Marketing Department, Middle East University, Jordan.
Rana K. Al-Soluiman (Jordan), Abdallah Q. Bataineh (Jordan),

Sameer M. Al-Jabaly (Jordan), Hanadi A. Salhab (Jordan)

THE IMPACT OF SMARTPHONE ADVERGAMES CHARACTERISTICS ON PURCHASING INTENTIONS: THE MEDIATING ROLE OF GAME INVOLVEMENT

\begin{abstract}
This research aimed to investigate the impact of smartphone advergames characteristics on purchasing intentions. Four dimensions were considered (irritation, entertainment, credibility, and informativeness). To achieve this aim, the researchers developed a model based on literature reviews and previous studies; a self-administrated questionnaire was designed and distributed over a convenience sample. The researchers used a quantitative method and a descriptive-analytical approach; the study sample consisted of 600 consumers, and 519 questionnaires were returned with an $86.5 \%$ response rate. Various statistical methods, including descriptive, simple linear regression, were used to analyze the data and test the hypotheses. This research's key findings were that there is a statistically direct impact of irritation, entertainment, credibility, and informativeness on consumers' purchasing intentions. Moreover, there is a mediating role of game involvement between advergames and consumers' purchasing intentions. Hence, many Jordanian companies can use smartphone mobile advertising to increase sales and create product brand image among consumers. Smartphone advergaming provides numerous opportunities and challenges for advertisers in the current dynamic business environment.
\end{abstract}

Keywords

advergames, irritation, entertainment, credibility, informativeness, purchasing intentions, online, Middle East, Jordan

JEL Classification $\quad$ M31, M37

\section{INTRODUCTION}

These days, the unstable and changeable conditions of the business environment forced organizations intensely to be entrepreneurial and agile, especially with the emergence of the internet and its advanced tools (Bataineh, Alhadid, Al-abdallah, Alfalah, Falah, \& Idris, 2015). The digitalization of media has resulted in innovative media outcomes, including mobile phones, which offers a wide scope to reach consumers easily and interact with them. Mobile phones, such as smartphones, can be effectively used as an advertising channel. Marketers recognize the unique features related to smartphones and use them to interact with prospective consumers. However, the internet has improved marketing effectiveness through its flexibility, speed, and low cost, which enabled the companies to replace their old-style promotional tools with efficient online techniques to create unique online models to communicate with their audience (Al-Abdallah \& Bataineh, 2018).

The spread of innovative mobile devices provided multisided and extremely targeted advertising interactive messages, even inside games. Furthermore, mobile gaming's fast growth has amplified the demand 
for mobile games as a strategic marketing platform (Newzoo, 2012). Therefore, there is increased desire from both researchers and practitioners to get informed about the new development, since it is perceived that the games nature and extended exposures to advertisements are the most relevant part of making profits on games as compared to traditional media. Earlier, game inventors have paid licensing fees to reflect real products/services into the games to improve reality, but today firms are ready to spend more to place their brands in the game to reach the increasing amount of online players (Kureshi \& Sood, 2009).

Mobile game advertising considered a new phenomenon; mobile phone game advertising service was launched in 2006 before brands were simply can be advertised in fixed, inflexible advertisements (Persaud \& Azhar, 2012). However, various information technology tools reshaped the relationships between customers and organizations and helped them take greater benefits of their current relationships (Bataineh et al., 2015). Since mobile game advertising is in its first steps, it is defensible to start examining mobile players, as the diffusion of innovative mobile technology is highly and quickly increasing in Jordan. Mobile gaming in the Jordanian market consumes $\$ 4$ of $\$ 10$ paid out by gamers in 2017 ; that figure will go up to $\$ 6$ out of every $\$ 10$ by 2020 , according to a recent forecast by ipsos.com. Based on in-depth investigation and analysis of the available advergames literature, the research problem stems from exploring smartphone advergames' impact on purchasing intentions in Jordan.

With the dramatic growth of smartphones and mobile applications globally and with the impact of this growth on the advertising business sector, the study's importance stems from its attempt to identify the impact of smartphone advergames on individual purchasing intentions. Based on the researchers' best knowledge, this will be the first research on smartphone advergames in the Arab nations since it has weak attention from scholars and practitioners, which enabled for the researchers to set up the cornerstone of this growing area to help entrepreneurial marketers who depend heavily on smartphones as a strategic tool to reach their target markets, as well as build a comprehensive model that describes consumers' attitudes towards smartphone advergames and demonstrate the probable role of consumer involvement as a key driver in consumers' purchasing decision-making process.

\section{LITERATURE REVIEW}

\subsection{Advergames}

Advergaming can be defined as the "use technology of gaming interactive to carry marketing messages to the individuals" (Dobrow, 2004). In general, advergames are free of charge and can be downloaded or played on websites, offering instant rewards like casual games setup (Redondo, 2012). Advergames are designed for both short and long playing times to be played during the day breaks, for instance, waiting times (Terlutter \& Capella, 2013). Moreover, consumers looking for adventure are considered bored and seek something unusual that supports their feelings of fantasy (Al-Obaidi, Bataineh, Aljabaly, \& Salhab, 2020).

The internet level has enhanced the level of game interactivity, with much probability of viral marketing occurrence (Călin, 2010). Nowadays, sev- eral advergames have more resources than traditional casual games and reached more complicated levels than others in the game industry, including videos, 3D graphics, and even console games like Xbox 360 (Antonsson \& Games, 2009). Over the last decade, internet development and mobile advergaming are becoming more observable and considerable in the advertisement. Evidence showed that solid brand recognition is typically increased from playing advergames; the interactivity and the repetitive entertainment significance were the key benefits of advergames (Cauberghe \& Pelsmacker, 2010).

\subsection{Advergames characteristics}

\subsubsection{Irritation}

In general, advertisement is known as irritation when it causes consumers' annoyance, disappointment, and dissatisfaction. Irritation refers 
to consumers' negative attitudes formed around the idea of mobile advertising (Altuna \& Konuk, 2009). According to the theory of psychological reactance for freedom and control, individuals tend to respond negatively when they recognize that their freedom is somehow lost or threatened (Wong, 2008). Therefore, Ercis (2011) considered irritation one of the most important factors driving consumers to ignore advertisements.

In particular, consumers and recipients might be confused by the information load that mobile advertising offers and which, in some cases, is considered a real invasion of their privacy (Stewart \& Pavlou, 2002). Many reasons make consumers recognize advertisements offensive and uncomfortable, and one of them is using unpleasant, aggressive, disrespectful, and dishonest advertising techniques (Tsang, 2004). In this study, irritation can be defined as the negative attitude of consumers toward mobile advertising. This variable can be measured through annoy, offend, insult, and overly manipulative.

\subsubsection{Entertainment}

Entertainment contains the capability to satisfy the audience's needs more than emotional and aesthetic enjoyment. It is shown as an activity or action, which is meant to attract, satisfy, and entertain users. In mobile advertising, there is a positive interaction between consumers' attitudes and entertainment, therefore, considered a cornerstone that assists in identifying and predicting consumers' attitudes in mobile advertising context (Zabadi, Shura, \& Elsayed, 2012). However, contradicting the finding that entertainment did not influence consumers' attitudes towards products was done by Christensen (2013). In this study, entertainment refers to the marketer's efforts in fulfilling consumers' needs for diversion, aesthetic, escapism, and emotional enjoyment through advertising. This variable can be measured through pleasure, feeling of enjoyment, and fun.

\subsubsection{Credibility}

Organization credibility can be defined as "the degree to which consumers trust that a company can design and provide products and services that can satisfy customer needs and wants" (Lee
\& Faber, 2007). However, when the consumer decides, he/she will calculate if the product is truthful in advance of using information depending on their prior experience with the advertisers (Christensen, 2013). Consequently, if the perceived credibility was high, advertising's value will increase (Islam, Kang, \& Yang, 2013). According to Zabadi et al. (2012), there is an influence of advertising credibility on consumers' attitudes toward the advertisement. In this study, credibility refers to the degree of consumers' belief and trust in product advertising through mobile gaming.

\subsubsection{Informativeness}

One of the advertising objectives is to update consumers about new or current products or let consumers know of any price modifications (Kotler \& Armstrong, 2016). Informativeness is defined as "advertising ability to convey updated, timely and simple information for consumers" (Altuna et al., 2009). Furthermore, information quality in advertising messages affects consumers' perceptions of the overall company image and its products (Usta, 2009). The main role of informativeness is to spread products-related information and deliver valuable offers (Daugherty, Logan, Chu, \& Huang, 2008). Wong and Tang (2008) showed that informativeness had been recognized as a key element for advertising. Perceived informativeness positively affects consumers' attitudes toward advertising (Tsang, Ho, \& Liang, 2004; Blanco, Blasco, \& Azorin, 2010). In this study, informativeness refers to advertising ability to let consumers know product features and alternatives to assure the utmost possible satisfaction for them. This variable can be measured through information accuracy, timeliness, and usefulness for the consumer.

\subsection{Purchasing intentions}

Marketers consider purchasing intentions as a tool that can predict the sales of existing goods and services (Kotler \& Armstrong, 2016). According to Kawa, Rahmadiani, and Kumar (2013), the six stages consumers go through before deciding to purchase a product are awareness, knowledge, interest, preference, persua- 
sion, and purchase. The likelihood of a consumer buying a product can be easily measured by consumer purchasing intention, and the greater the purchasing intention, the higher a consumer's willingness to buy a product (Schiffman \& Kanuk, 2012). Consumers will follow their experiences, preferences, and external environment to gather information, assess alternatives, and make a purchase decision (Yang, 2009). Moreover, consumers' purchasing intentions will be greater with a higher preference image and familiarity for the product (Wang, 2006). In general, consumers evaluate the benefits they receive for what they had sacrificed to get their perceived satisfaction (Ridgway \& Kukar-Kinney, 2012). Previous research studies on purchasing intentions among consumers considered that intentions are a vital variable for predicting consumers' actual purchasing. In advertising aspects, purchasing intentions data is used to evaluate and pre-test the marketing and promotional plans for both the newly developed and existing ones. According to Kotler and Armstrong (2016), purchasing intentions are viewed as an indicator of consumer buying behavior, and the information is used as a good measure in determining specific behavioral aspects.

\subsection{The mediating role of game involvement in advergames}

According to Abdulvand and Nikfa (2011), there is no perfect definition of involvement in marketing literature; there is an agreement that involvement is an intrinsic variable, reflecting the personal connection of goals. Involvement is used to determine the relative importance of people's values, interests, and essentially their needs for certain items (Zaichkowsky, 1985). Some definitions considered unobservable involvement state of enthusiasm or interest in a particular situation or motivation (Rothschild, 1984). However, involvement has two different but very much connected dimensions: importance and interest (McQuarrie \& Munson, 1992). Importance can be recognized by stimulus meaning and relevance (e.g., it really matters to me), while interest is about emotion and value-related valences, such as "it was very exciting".
Game category involvement in advergames has been recognized by many scholars to have a considerable influence on evaluating consumers' advertising and purchasing intentions (Rai, 2013). Previous studies about consumers' attitudes towards product and game involvement exposed that many participants trust and have a positive attitude towards this practice and, in general, do not considers that the commercial interrupts with their knowledge of the game (Nelson, 2002). In this study, involvement refers to the consumer's inner state used to reveal an on-going interest of a product derived from the importance of the purchasing process. This variable can be measured through time, preferences, and alternatives.

\section{RESEARCH HYPOTHESES}

Based on the literature discussed earlier, the following hypotheses were generated to answer the research problem statement in the first section:

H01: There is no impact of irritation on consumers' purchasing intentions at a significant level $(\alpha \leq 0.05)$.

H02: There is no impact of entertainment on consumers' purchasing intentions at a significant level $(\alpha \leq 0.05)$.

H03: There is no impact of credibility on consumers' purchasing intentions at a significant level $(\alpha \leq 0.05)$.

H04: There is no impact of informativeness on consumers' purchasing intentions at a significant level ( $\alpha \leq 0.05)$.

H05: There is no mediating role of game involvement between advergames and consumers' purchasing intentions at a significant level $(\alpha \leq 0.05)$.

\section{RESEARCH MODEL}

To facilitate testing the relationships between the research variables, the researchers developed this model based on previous studies. 


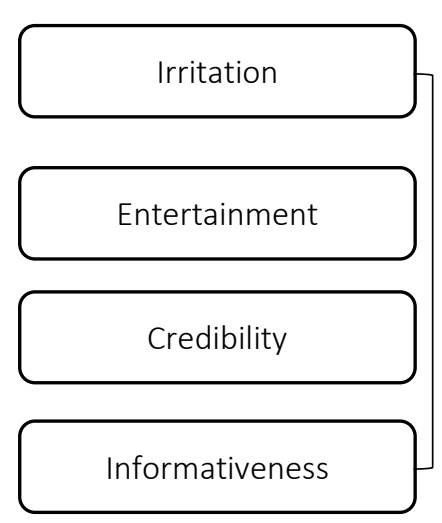

Figure 1. Research model

\section{METHODS}

\subsection{Population and study sample}

The study population consisted of all who have smartphones and play online games on the smartphone in Jordan. Accordingly, each respondent should meet the following sample selection criteria: (1) have a smartphone, (2) play online games on a smartphone.

According to Sekaran and Bougie (2013), the sample size will depend on the desired confidence interval for an infinite population. If the study is arranged to accept an error level of 5\%, then the study requires a sample size of 400 observations. Accordingly, a convenience sample was adopted in this study by distributing 600 questionnaires. 519 questionnaires were received with an $86.5 \%$ response rate. After reviewing and assessing the received questionnaires, 7 questionnaires out of 519, which represent $1.35 \%$, were excluded due to incomplete data essential for the study analyses. Therefore, the sample selection criteria were applied to 512 questionnaires.

1. Do you have a smartphone?

Table 1. Frequency distribution of the study sample based on "Do you have a smartphone?"

\begin{tabular}{l|c:c}
\hline \multicolumn{1}{c|}{ Category } & Frequency & Percentage \\
\hline Yes & 493 & $96.3 \%$ \\
\hline No & 19 & $3.7 \%$ \\
\hline Total & 512 & $100 \%$ \\
\hline
\end{tabular}

Table 1 shows that 493 respondents out of 512, representing $96.3 \%$ of the initial sample, have smart- phones. However, 19 respondents out of 512, representing $3.7 \%$ of the initial sample, do not have smartphones. Accordingly, 19 questionnaires were excluded, and the sample became 493 after applying the first criterion.

2. Do you play online games on your smartphone?

Table 2. Frequency distribution of the study sample based on "Do you play online games on your smartphone?"

\begin{tabular}{l|c|c}
\hline \multicolumn{1}{c|}{ Category } & Frequency & Percentage \\
\hline Yes & 406 & $82.4 \%$ \\
\hline No & 87 & $17.6 \%$ \\
\hline Total & 493 & $100 \%$ \\
\hline
\end{tabular}

Table 2 shows that 406 respondents out of 493 represent $82.4 \%$ and play online games on their smartphones. However, 87 out of 493 respondents, representing $17.6 \%$, do not play online games on their smartphones. Accordingly, 87 questionnaires were excluded, and the sample became 406 after applying the second criterion.

\subsection{Research instrument}

Based on a thorough analysis of previous studies measurements, the researchers developed a self-administered questionnaire where a 5-point Likert scale was used to measure the respondents' answers, ranging from strongly disagree to strongly agree. The research instrument consists of three parts. The first part is a cover letter that indicates the study's aims by ensuring the confidentiality of the information and the privacy for respondents by indicating that the information 
will be used only for academic research purposes.

The second part deals with the questions related to sample selection criteria and the study sample's demographic information, which consisted of 4 questions related to respondents' playing hours of online games on their smartphone, age, educational level, and income.

The third part consists of questionnaire's questions regarding study variables where the first section deals with the irritation factor using 4 questions followed by entertainment factor with 4 questions; credibility factor with 3 questions; informativeness with 5 questions; game involvement, which is employed as mediating variable with 10 questions; and consumers' purchasing intention, which is considered the dependent variable of the study with 5 questions.

\subsection{Instrument validity}

The validity of the research instrument of the study was verified in two ways:

1) pilot study - the research instrument was initially distributed to 50 respondents; 27 questionnaires were received with a $54 \%$ response rate; the respondents asked to express their opinions whether the statements of the questionnaire were understandable, clear, the language is simple; therefore, the necessary modifications were made to the questionnaire;

2) face validity - the research instrument of the study was assessed by a panel of experts, with a total of 6 experts from reputable electronic and digital marketing companies in Jordan; the opinions and feedback of the experts were considered, and the required modifications were made.

\subsection{Reliability analysis}

To make sure that the study's questionnaire measured what was supposed to be measured and the internal consistency of the instrument of the study, the Cronbach's Alpha approach was employed. Tables 3-6 document the outcomes of reliability analysis using Cronbach's Alpha approach.

The results pointed out that the Cronbach's alpha coefficients range from 0.683 , referred to informativeness items, to 0.931 , which referred to game involvement items. According to Sekaran and Bougie (2013), all Cronbach's alpha coefficient values above 0.6 are considered acceptable.

\section{RESULTS}

\subsection{Descriptive statistics of the study sample}

This sub-section presents the descriptive statistics of the study sample (i.e., 406 respondents) using the frequency and percentage for all demographics dimensions of the study, which consisted of 4 dimensions, namely respondents' playing hours a day, age, education, and income.

Table 4. Distribution of sample based on their playing hours a day

\begin{tabular}{|c|c|c|c|}
\hline $\begin{array}{c}\text { Demographic } \\
\text { variable }\end{array}$ & Category & Frequency & Percentage \\
\hline \multirow{5}{*}{ Playing hours a day } & $\begin{array}{l}\text { Less than } 1 \\
\text { hour }\end{array}$ & 11 & $2.7 \%$ \\
\hline & $\begin{array}{l}\text { From } 1 \text { to } 2 \\
\text { hours }\end{array}$ & 42 & $10.3 \%$ \\
\hline & $\begin{array}{l}\text { From } 3 \text { to } 4 \\
\text { hours }\end{array}$ & 234 & $57.6 \%$ \\
\hline & $\begin{array}{l}\text { More than } 4 \\
\text { hours }\end{array}$ & 119 & $29.3 \%$ \\
\hline & Total & 406 & $100 \%$ \\
\hline
\end{tabular}

Table 3. Reliability analysis - Cronbach's Alpha approach

\begin{tabular}{|c|c|c|c|}
\hline Variable & Dimension & No. of items & Cronbach's alpha coefficients \\
\hline \multirow{4}{*}{ Independent } & Irritation & 4 & 0.897 \\
\hline & Entertainment & 4 & 0.877 \\
\hline & Credibility & 3 & 0.711 \\
\hline & Informativeness & 5 & 0.683 \\
\hline \multicolumn{2}{|c|}{ Total advergames characteristics } & 16 & 0.908 \\
\hline Mediating & Game involvement & 10 & 0.931 \\
\hline Dependent & Purchasing intentions & 5 & 0.888 \\
\hline
\end{tabular}


Table 5. Distribution of respondents' age

\begin{tabular}{|c|c|c|c|}
\hline Demographic variable & Category & Frequency & Percentage \\
\hline \multirow{6}{*}{ Age } & Less than 18 years & 2 & $.493 \%$ \\
\hline & 18 - less than 28 years & 293 & $72.2 \%$ \\
\hline & 28 - less than 38 years & 95 & $23.4 \%$ \\
\hline & 38 - less than 48 years & 14 & $3.4 \%$ \\
\hline & More than 48 years & 2 & $.493 \%$ \\
\hline & Total & 406 & $100 \%$ \\
\hline
\end{tabular}

Table 4 depicts the distribution of the respondents based on their playing hours of online games a day. As can be observed from the table, 234 respondents out of 406 represent $57.6 \%$ of the study sample spending 3-4 hours a day playing online games. Also, 119 respondents out of 406 represented 29.3\% of the study sample spending more than 4 hours a day playing online games. However, 11 respondents out of 406 represent $2.7 \%$ spending less than 1 hour a day playing online games. The majority of the study sample (i.e., $86.9 \%$ ) plays online games from 3 hours and above, which implies that the study sample is considered relatively representative of those who enjoy playing online games.

Table 5 shows the distribution of the respondents based on age. As revealed in the table, the age of 293 respondents out of 406, which represent $72.2 \%$ of the study sample, was 18 - less than 28 years, since young individuals would be more interested in spending their time playing advergames with fewer responsibilities they have at that age, which allowed them more time to play. Furthermore, the age of 95 respondents out of 406, representing $23.4 \%$ of the study sample, was 28 - less than 38 years. However, the age of 2 respondents was less than 18 years. The age of most respondents (i.e., $95.6 \%)$ was 18 - less than 38 years.

Table 6 shows the distribution of the respondents based on their educational level. As observed in the table, 296 respondents out of 406, which represent $72.9 \%$ of the study sample, had a Bachelor's degree; this can be explained with more free time this level has. Moreover, the educational level of 107 respondents out of 406 , representing $26.36 \%$ of the study sample, was a Master's degree. However, the educational level of 2 respondents out of 406, representing $.493 \%$ (i.e., less than $1 \%$ of the study sample), was high school or less. Whereas the educational level of 1 respondent was Doctor of Philosophy, the higher the maturity level, the lower the interest of such games.

Table 7 shows the distribution of the respondents based on their income. As depicted in the table, the income of 260 respondents out of 406, representing $64 \%$ of the study sample, was 500 - less than 1,000 $\mathrm{JD}$, which expresses the normal range of salaries in Jordan. Moreover, 114 respondents out of 406, representing $28.1 \%$ of the study sample, had less than 500 JD. Whereas, 2 respondents, which represent $0.493 \%$ (i.e., less than 1\%), had more than 1,500 JD.

Table 6. Distribution of respondents' educational level

\begin{tabular}{|c|c|c|c|}
\hline Demographic variable & Category & Frequency & Percentage \\
\hline \multirow{5}{*}{ Education } & High school or less & 2 & $.493 \%$ \\
\hline & Bachelor's degree & 296 & $72.9 \%$ \\
\hline & Master's degree & 107 & $26.36 \%$ \\
\hline & Doctor of Philosophy & 1 & $.246 \%$ \\
\hline & Total & 406 & $100 \%$ \\
\hline
\end{tabular}

Table 7. Distribution of respondents' income (JDs)

\begin{tabular}{l|c|c|c}
\hline \multicolumn{1}{c}{ Demographic variable } & Category & Frequency & Percent \\
\hline & Less than 500 & 114 & $28.1 \%$ \\
Income & $500-$ less than 1,000 & 30 & 260 \\
& $1,000-$ less than 1,500 & 2 & $7.4 \%$ \\
& More than 1,500 & 406 & 100 \\
\hline
\end{tabular}




\subsection{Normality test}

The normality data assessment is a cornerstone for numerous statistical tests since normal data rely on the fundamental assumption in parametric tests, particularly normal distributions assumed in regression analysis, non-normally distributed variables (i.e., kurtosis and skewed variables, or variables with significant outliers) can distort relationships forms (Osborne \& Waters, 2002). Table 8 presents the skewness and kurtosis values of each of the study variables.

Table 8. Skewness and kurtosis values of each of the study variables

\begin{tabular}{l|c:c}
\hline \multicolumn{1}{c}{ Variable } & Skewness & Kurtosis \\
\hline Irritation & .443 & .156 \\
\hdashline Entertainment & -.180 & .003 \\
\hline Credibility & -.343 & -.655 \\
\hline Informativeness & .471 & .749 \\
\hdashline Game involvement & -.423 & -.661 \\
\hline Purchasing intentions & -.254 & -.304 \\
\hline
\end{tabular}

It can be observed from Table 8 that the skewness values for the study variables range from -0.423 to .471 , and kurtosis values for all variables varied between -0.661 and .749 , which suggests that the data are approximately normally distributed, and using linear regression is considered appropriate.

\subsection{Multicollinearity test}

Table 9 presents tolerance and variance inflation factor (VIF) tests, where multicollinearity problems exist when VIF is larger than 10, and the tolerance level is less than 0.05 (Gujarati, 2009). Based on that, the problem of multicollinearity in interpreting the regression analysis results did not exist.

Table 9. Collinearity statistics results

\begin{tabular}{l|c:c}
\hline \multirow{2}{*}{ Variable } & \multicolumn{2}{c}{ Collinearity statistics } \\
\cline { 2 - 3 } & Tolerance & VIF \\
\hline Irritation & .909 & 1.100 \\
\hdashline Entertainment & .849 & 1.178 \\
\hdashline Credibility & .855 & 1.170 \\
\hdashline Informativeness & .859 & 1.164 \\
\hline
\end{tabular}

\subsection{Durbin-Watson statistics}

Table 10 shows Durbin-Watson statistics, used to know the probability of autocorrelation occurrence in the relationship among separated values through a certain time lag of residuals (prediction errors) within the regression test (Gertzou, Karabagias, Drosos, \& Riganakos, 2017).

Table 10. Durbin-Watson statistics results

\begin{tabular}{l|c}
\hline \multicolumn{1}{c|}{ Variable } & Durbin-Watson \\
\hline Irritation & 2.056 \\
\hline Entertainment & 2.087 \\
\hline Credibility & 2.015 \\
\hline Informativeness & 2.111 \\
\hline Advergames & 2.163 \\
\hline
\end{tabular}

Table 10 shows the values of Durbin-Watson on each of the study variables. According to Gujarati (2009), autocorrelation means that the adjacent errors of observations are correlated, so if they are correlated, then the least-squares regression can undoubtedly underestimate the coefficients of standard errors. Based on that, no autocorrelation exists if the Durbin-Watson statistics fall between 1.5 and 2.5 .

Table 10 shows that the Durbin-Watson values range between 2.056 and 2.163, which suggests no presence of autocorrelation in the prediction errors of regression analysis.

\subsection{Hypotheses testing}

To achieve the research objectives, simple linear regression and hierarchical linear regression were run.

Table 11 shows the results of testing the first hypothesis, which states: "There is no impact of irritation on consumers' purchasing intentions at the significant level $(\alpha \leq 0.05)$ " using simple linear regression.

Table 11. Simple linear regression for testing the first hypothesis

\begin{tabular}{c|c|c|c}
\hline Variable & Beta coefficient & T-value & Sig. \\
\hline Irritation & -.247 & -5.117 & .000 \\
\hdashline F-value $=26.188$ & & $R=.247$ \\
\hdashline Sig. $=0.000$ & $R^{2}=.061$ \\
\hline
\end{tabular}


The outcomes of simple linear regression testing on the impact of irritation on consumers' purchasing intentions were significant $(F=26.188)$ and $p=0.000$, suggesting that the model is statistically valid. The results revealed that the value of $R^{2}$ was 0.061 , which means that $6.1 \%$ of consumers' purchasing intentions are explained by irritation factor.

As shown in Table 11, the consumers' purchasing intentions are affected negatively by irritation at 0.05 level of significance, where the beta coefficient was -0.247 , with $t$-value $(-5.117)$ and $p$-value (0.000). Accordingly, H01 has been rejected.

Table 12 provides the outcomes of the second hypothesis, which states: "There is no impact of entertainment on consumers' purchasing intentions at the significant level $(\alpha \leq 0.05)$ " using simple linear regression.

Table 12. Simple linear regression for testing the second hypothesis

\begin{tabular}{l|c|c|c}
\hline \multicolumn{1}{c|}{ Variable } & Beta coefficient & T-value & Sig. \\
\hline Entertainment & .391 & 8.549 & .000 \\
\hdashline F-value $=73.088$ & & $R=.391$ \\
\hline Sig. $=0.000$ & & $R^{2}=.153$ \\
\hline
\end{tabular}

The outcomes of simple linear regression testing on the impact of entertainment on consumers' purchasing intentions were significant $(F=73.088)$ and $p=0.000$, suggesting that the model is statistically valid. The results revealed that the value of $R^{2}$ was 0.153 , which means that $15.3 \%$ of consumers' purchasing intentions are explained by the entertainment factor, suggesting a strong and high explanatory power. The results revealed that entertainment positively influences the consumers' purchasing intentions at 0.05 level of significance, where the values of the beta coefficient (0.391), $t$-value (8.549), and $p$-value (0.000) statistically approved such influence. Accordingly, HO2 has been rejected.

Table 13 illustrates the findings of testing the third hypothesis, which states: "There is no impact of credibility on consumers' purchasing intentions at the significant level $(\alpha \leq 0.05)$ " using simple linear regression.
Table 13. Simple linear regression for testing the third hypothesis

\begin{tabular}{|c|c|c|c|}
\hline Variable & Beta coefficient & $T$-value & Sig. \\
\hline Credibility & .341 & 7.280 & .000 \\
\hline$F$-value $=53.003$ & & \multicolumn{2}{|c|}{$R=.341$} \\
\hline Sig. $=0.000$ & & \multicolumn{2}{|c|}{$R^{2}=.116$} \\
\hline
\end{tabular}

The outcomes of simple linear regression testing the impact of credibility on consumers' purchasing intentions were found to be significant $(F=53.003)$ and $p=0.000$, suggesting that the model is statistically valid. The results revealed that the value of $R^{2}$ was 0.116 , which means that $11.6 \%$ of consumers' purchasing intentions are explained by the credibility factor, suggesting a strong and high explanatory power. It can be noticed from Table 13 that the consumers' purchasing intentions are affected positively by credibility at 0.05 level of significance, with a beta coefficient (0.341), $t$-value (7.280), and $p$-value (0.000). Accordingly, $\mathrm{H} 03$ has been rejected.

Table 14 presents the results of testing the fourth hypothesis, which states: "There is no impact of informativeness on consumers' purchasing intentions at the significant level $(\alpha \leq 0.05)$ " using simple linear regression.

Table 14. Simple linear regression for testing the fourth hypothesis

\begin{tabular}{l|c:c:c}
\hline \multicolumn{1}{c}{ Variable } & Beta coefficient & T-value & Sig. \\
\hline Informativeness & .285 & 5.974 & .000 \\
\hdashline -value $=35.683$ & & & $R=.285$ \\
\hline Sig. $=0.000$ & & $R^{2}=.081$ \\
\hline
\end{tabular}

The outcomes of simple linear regression testing on the impact of informativeness on consumers' purchasing intentions were significant $(F=35.683)$ and $p=0.000$, suggesting that the model is statistically valid. The results revealed that the value of $R^{2}$ was 0.081 , which means that the informativeness factor explains $8.1 \%$ of consumers' purchasing intentions. It can be observed from table 14 that informativeness positively influences the consumers' purchasing intentions at 0.05 level of significance with a beta coefficient of 0.285 , $t$-value 5.974, and p-value 0.000. Accordingly, H04 has been rejected.

To test the fifth hypothesis, the hierarchical linear regression was run. Table 15 provides the re- 
Table 15. Hierarchical linear regression for testing the second main hypothesis

\begin{tabular}{|c|c|c|c|c|c|c|c|}
\hline Effect direction & $\mathbf{R}$ & $R^{2}$ & $\mathbf{F}$ & $\operatorname{Sig}(f)$ & Beta coefficients & $\mathbf{T}$ & $\operatorname{Sig}(t)$ \\
\hline $\begin{array}{l}\text { Smartphone advergames characteristics on consumer } \\
\text { purchasing intentions }\end{array}$ & .334 & .111 & 50.646 & .000 & .334 & 7.117 & .000 \\
\hline Mediation of game involvement & .493 & .243 & 64.745 & .000 & .382 & 8.377 & .000 \\
\hline
\end{tabular}

sults of testing the fifth hypothesis of the study, which states: "There is no mediating role of game involvement between advergames and consumers' purchasing intentions at the significant level $(\alpha \leq 0.05)$ ".

The results of hierarchical linear regression found that the impact of smartphone advergames characteristics on consumers' purchasing intentions without including the mediation of game involvement was statistically significant at 0.05 level of significance, beta coefficient (.334), $t$-value (7.117), and $p$-value (0.000). Furthermore, $F=50.646$ and $p=0.000$, which means that the model is statistically valid, whereas the explanatory power is $11.1 \%$.

As can be observed in Table 15, the game involvement mediates the relationship between advergame characteristics and consumers' purchasing intentions, where $R^{2}$ increased from $11.1 \%$ to $24.3 \%$, which considered a great change in the explanatory power. Consequently, H05 has been rejected.

\section{DISCUSSION}

There is a statistically direct impact of smartphone advergames irritation on consumers' purchasing intentions. However, the impact is low to moderate since the value of $R=0.247$. There is a statistically direct impact of smartphone advergames entertainment on consumers' purchasing intentions. However, the impact is low to moderate since the value of $R=0.391$. There is a statistically direct impact of smartphone advergames credibility on consumers' purchasing intentions. However, the impact is low to moderate since the value of $R=0.341$. There is a statistically direct impact of smartphone advergames informativeness on consumers' purchasing intentions. However, the impact is low to moderate since the value of $R=0.285$. There is a statistically direct mediation role of game involvement on purchasing intentions, the value of $R=0.493$.

The era of information technology (IT) provided organizations with various means to reach and serve their target audience (Bataineh, 2015). Consequently, the impact of irritation on consumers' purchasing intentions was consistent with Chowdhury, Parvin, Weitenberner, and Becker (2010), which suggested that advertising messages must be distributed only to consumers interested in receiving information from companies and avoiding consumers who think advertising messages being irritating. For the entertainment impact on consumers' purchasing intentions, the findings support the fact that advergames should be more exciting; this result is in line with Xu (2007), Zabadi et al. (2012) who confirmed that mobile advertising must be funny and to include attractive pictures, videos or sounds. In terms of credibility, the findings revealed that when consumers trust and believe in the advertising messages, they tend to have a positive image regarding the brand; this result is in line with Brackett and Carr (2001), Wang (2006). For informativeness, the findings revealed that not only in mobile advertising but also in traditional media, informativeness influences attitude toward advertising. This result was consistent with Aitken, Gray, and Lawson (2008) who stated when consumers perceive advertisement as helpful and contain valuable information, they will respond positively to it. There is a statistically direct mediation role of game involvement in purchasing intentions. Finally, for the mediating role of game involvement, it was significant and in line with many studies (Kim, 2003; Cabanero, 2006) who stated that involvement is a vital variable in marketing studies, social-psychology consumers' behavior and has a noticeable effect on purchasing intentions. 


\section{CONCLUSION}

Nowadays, smartphone advergaming is considered one of the best personal communication channels that involve both the sender and the receiver for conveying information to one another. Besides, smartphone advergaming has the best to reach out the frequency and influences different exposure to the targeted consumers. However, the advertising content, structure, and format in advergames should be attractive, accurate, and acceptable by the target consumers. Clarified advertisements and communication may increase the efficiency of gaining important information, leading to high sales volume and better consumer loyalty.

This research contributes to the theoretical and marketing understanding of consumer attitude towards smartphone advergaming in Jordan. At a theoretical level, this study has contributed greater knowledge and understanding of the various variables that appear responsible for structuring consumers' attitudes towards smartphone advergaming on purchasing intentions and the mediating role of game involvement. In this perspective, the model means that when a customer forms a certain attitude towards smartphone advergaming, that consumer may later retrieve the constructs directly related to the same scenario. It is important to know which factors contribute to a negative attitude towards smartphone advergaming and how such attitudes can be changed to attain the organization's set objectives and goals. From the practical point of view, this paper's finding has considerably clarified the confusing roles of informativeness, entertainment, credibility, and irritation in the aspect of smartphone advergaming. Practitioners can use these findings in designing promotional and marketing programs with smartphones that create positive attitudes at the expense of negative effects.

Finally, many Jordan companies can use smartphone mobile advertising to relatively increase sales and create product brand image among consumers. Smartphone advergaming provides numerous opportunities and challenges for advertisers in the current dynamic business environment. This study addresses a new topic, which has not been employed much in Jordan but may set a framework and become a central theme of research interest in practical and academic approaches. However, the researchers suggest the following future studies: (1) this study has attempted to outline major variables that influence attitude towards smartphone advergaming in Jordan; the data were collected among smartphone holders within Jordan locality, (2) the data collected were based on a convenience sample in Jordan, which may have resulted in sample biases. Finally, a comparative study of this model with other regions might lead to building a new model for advergames characteristics and its relationship with consumer behavior in general.

\section{ACKNOWLEDGMENT}

The authors are grateful to the Middle East University, Amman, Jordan, for the full financial support granted to this research project.

\section{AUTHOR CONTRIBUTIONS}

Conceptualization: Rana K. Al-Soluiman, Abdallah Q. Bataineh.

Data curation: Abdallah Q. Bataineh.

Formal analysis: Rana K. Al-Soluiman.

Funding acquisition: Abdallah Q. Bataineh.

Investigation: Rana K. Al-Soluiman, Hanadi A. Salhab.

Methodology: Rana K. Al-Soluiman, Sameer M. Aljabaly.

Project administration: Abdallah Q. Bataineh.

Resources: Abdallah Q. Bataineh, Hanadi A. Salhab.

Software: Sameer M. Aljabaly.

Supervision: Abdallah Q. Bataineh. 
Validation: Hanadi A. Salhab.

Visualization: Sameer M. Aljabaly.

Writing - original draft: Rana K. Al-Soluiman.

Writing - review \& editing: Abdallah Q. Bataineh.

\section{REFERENCES}

1. Abdolvand, M., \& Nikfar, F. (2011). Investigation of the Relationship between Product Involvement and Brand Commitment. Marketing Management, 13, 75-94.

2. Aitken, R., Gray, B., \& Lawson, R. (2008). Advertising effectiveness from a consumer perspective. International Journal of Advertising, 27(2), 279-297. https://doi.org/10.10 80/02650487.2008.11073055

3. Al-Abdallah, G., \& Bataineh, A. (2018). Social networking sites and fashion E-purchasing process. Journal of Business and Retail Management Research (JBRMR), 13(2). Retrieved from https://www. academia.edu/38388054/Social_networking_sites_and_fashion_E_purchasing_process

4. Al-Obaidi, L., Bataineh, A., Aljabaly, S., \& Salhab, H. (2020). Factors influencing youths fashion leadership behavior of fashion retailing stores in Jordan. Management Science Letters, 10(16) 3833-3842.

5. Altuna, O. K., \& Konuk, F. A. (2009). Understanding consumer attitudes toward mobile advertising and its impact on consumers' behavioral intention: A cross-market comparison of U.S. and Turkish consumers. International Journal of Mobile Marketing, 4(2), 43-51.

6. Antonsson, J. B., \& Games, G. (2009). Advergame Specific Design Principles. 2008-2009 Casual Games (White Paper, 104).

7. Bataineh, A. Q. (2015). The Effect of eCRM Practices on eWOM on Banks' SNSs: The Mediating Role of Customer Satisfaction. International Business Research, 8 , 230-243. Retrieved from https:// www.researchgate.net/publication/276515387_The_Effect_of_ eCRM_Practices_on_eWOM_on_ Banks'_SNSs_The_Mediating_Role_ of_Customer_Satisfaction

8. Bataineh, A., Alhadid, A., Alabdallah, G., Alfalah, T., Falah,
J., \& Idris, M. (2015). The Role of Information Technology Capabilities in Capitalizing Market Agility in Jordanian Telecommunications Sector. International Journal of Academic Research in Business and Social Sciences, 5(8), 90-101. Retrieved from https://ideas.repec.org/a/hur/ ijarbs/v5y2015i8p90-101.html

9. Blanco, C. F., Blasco, M. G., \& Azorin, I. I. (2010). Entertainment and informativeness as precursory factors of successful mobile advertising messages. In Communications of the International Business Information Management Association (pp. 130-147). Retrieved from https://www.researchgate.net/ publication/41845853_Entertainment_and_Informativeness_as_Precursory_Factors_of_Successful_Mobile_Advertising_Messages

10. Cabanero, C. P. (2006). Consumer involvement in goods and service purchases. University of Valencia.

11. Călin, G. (2010). Advergames: Characteristics, Limitations and Potential. Annals of Faculty of Economics, 1(1), 726-730. Retrieved from https://ideas.repec.org/a/ora/ journl/v1y2010ilp726-730.html

12. Cauberghe, V., \& Pelsmacker, P. D. (2010). Advergames. Journal of Advertising, 39(1), 5-19.

13. Chowdhury, H. K., Parvin, N., Weitenberner, C., \& Becker, M. (2010). Consumer attitude toward mobile advertising in an emerging market: An empirical study. Marketing, 12(2), 206-216.

14. Christensen, M. (2013). New media geographies and the Middle East. Television and New Media, 14(4), 267-270. https://doi.org/ $10.1177 \% 2 F 1527476413481856$

15. Daugherty, T., Logan, K., Chu, S. C., \& Huang, S. C. (2008). Understanding consumer perception of advertising: A theoretical framework of attitude and confidence. In American Academy of Advertising (pp. 308313). Retrieved from https:// www.researchgate.net/publication/272494516_Understanding_Consumer_Perceptions_of_ Advertising_A_Theoretical_Framework_of_Attitude_and_Confidence

16. Dobrow, L. (2004, January 15). How to Play Games and Influence People: Advergaming Emerges as New Ad Option. Media Daily News.

17. Gertzou, I., Karabagias, I., Drosos, P., \& Riganakos, K. (2017). Effect of combination of ozonation and vacuum packaging on shelf life extension of fresh chicken legs during storage under refrigeration. Journal of Food Engineering, 213, 18-26. Retrieved from https:// www.researchgate.net/publication/317802120_Effect_of_combination_of_ozonation_and_vacuum packaging_on_shelf_life_extension_ of_fresh_chicken_legs_during_storage_under_refrigeration

18. Islam, M., Kang, M., \& Yang, S. B. (2013). A research to identify the relationship between consumers' attitude and mobile advertising. In PACIS 2013 Proceedings, 39.

19. Kawa, L. W., Rahmadiani, $S$ F., \& Kumar, S. (2013). Factors Affecting Consumer Decision Making: A Survey of YoungAdults on Imported Cosmetics in Jabodetabek, Indonesia. The SIJ Transactions on Industrial, Financial $\&$ Business Management (IFBM), 1(5). Retrieved from https://www. academia.edu/6899789/Factors_Affecting_Consumer_Decision_Making_A_Survey_of_Young Adults_on_Imported_Cosmetics_in_Jabodetabek_Indonesia

20. Kim, Y. (2003). Conceptualizing Health Campaign Strategies through the Level of Involvement. Corporate Communication: an International Journal, 
8(4), 255-267. https://doi. org/10.1108/13563280310506421

21. Kotler, P., \& Armstrong, G. (2016). Principles of Marketing (16th ed.). Boston: Pearson Education.

22. Kukar-Kinney, M., Ridgway, N, M., \& Monroe, K. B. (2012). The Role of Price in the Behavior and Purchase Decisions of Compulsive Buyers. Journal of Retailing (Special Issue on Pricing), 88(1), 63-71. https://doi. org/10.1016/j.jretai.2011.02.004

23. Kureshi, S., \& Sood, V. (2009). Indian Gamers' Recall, Recognition and Perceptions of In-Game Placement. Journal of Indian Business Research, 1(4), 252268. Retrieved from https:// www.researchgate.net/publication/240261023_Indian_gamers' recall_recognition_and_perceptions_of_in-game_placements

24. Lee, M., \& Faber, R. J. (2007). Effects of product placement in on-line games on brand memory: A perspective of the limited-capacity model of attention. Journal of Advertising, 36(4), 75-90. Retrieved from https://www.researchgate.net/ publication/233894829_Effects_of_ Product_Placement_in_On-Line_ Games_on_Brand_Memory_A_ Perspective_of the_Limited-Capacity_Model_of_Attention

25. McQuarrie, E. F., \& Munson, J. M. (1992). A revised product involvement inventory: Improved usability and validity. Advances in Consumer Research, 19, 108115. Retrieved from https://www. acrwebsite.org/volumes/7277/volumes/v19/NA-19

26. Nelson, M. R. (2002). Recall of brand placements in computer/ video games. Journal of Advertising Research, 42(2), 80-93. Retrieved from http://www.journalofadvertisingresearch.com/content/42/2/80

27. Newzoo. (2012). Mobile Games Trend Report. Retrieved from http:// www.newzoo.com/trend-reports/ mobile-games-trend-report/

28. Persaud, A., \& Azhar, I. (2012). Innovative Mobile Marketing via Smartphones: Are consumers ready? Marketing Intelligence \& Planning, 30(4), 418-443. Retrieved from https://www.researchgate.net/ publication/235307685_Innovative_mobile_marketing_via_smartphones_Are_consumers_ready
29. Rai, N. (2013). Impact of Advertising on Consumer Behaviour and Attitude with Reference to Consumer Durables. International Journal of Management Research and Business Strategy, 2(2). Retrieved from https://www. academia.edu/31955064/IMPACT OF_ADVERTISING_ON_CONSUMER_BEHAVIOUR_AND_ATTITUDE_WITH_REFERENCE TO_CONSUMER_DURABLES

30. Redondo, I. (2012). The Effectiveness of Casual Advergames on Adolescents' Brand Attitudes. European Journal of Marketing, 46(11/12), 1671-1688. https://doi. org/10.1108/03090561211260031

31. Ridgway, N. M., \& Kukar-Kinney, M. (2012). The Role of Price in the Behavior and Purchase Decisions of Compulsive Buyers. Journal of Retailing (Special Issue on Pricing), 88(1), 63-71. Retrieved from https://www.researchgate.net/ publication/236964821_The_Role_ of_Price_in_the_Behavior_and Purchase_Decisions_of_Compulsive_Buyers

32. Rothschild, M. L. (1984) Perspectives on involvement: Current problems and future directions. Advances in Consumer Research, 11, 216-217. Retrieved from https://web.b.ebscohost.com/ abstract?direct $=$ true\&profile $=$ ehos $\mathrm{t} \&$ scope $=$ site\&authtype $=$ crawler $\&$ jrnl $=00989258 \& A N=6434133 \& \mathrm{~h}=$ gPqxhz9dLzkNI8jyzbJvKWA7jrr6r QKU3lQZvqDIhAo87CfdTUVNK gThEhRMGjmdXDLFyUOhXQE42 kDw5QqdZw\%3d\%3d\&crl=c\&resul $\mathrm{tNs}=$ AdminWebAuth\&resultLocal $=$ ErrCrlNotAuth\&crlhashurl=login.as px\%3fdirect\%3dtrue\%26profile \%3d ehost\%26scope\%3dsite\%26authtype \%3dcrawler\%26jrnl\%3d00989258\% 26AN\%3d6434133

33. Schiffman, L. G., Kanuk, L. L., \& Hansen, H. (2012). Consumer Behaviour: A European Outlook (2nd ed). Essex: Pearson Education.

34. Sekaran, U., \& Bougie, R. (2013). Research methods for business (6th ed.). John Wiley \& Sons, Inc.

35. Stewart, D. W., \& Pavlou, P. A. (2002). From consumer response to active consumer: measuring the effectiveness of interactive media. Journal of the Academy of Marketing Science, 30(4), 376-396. Retrieved from https://link.springer.com/article/10.1177/009207002236912

36. Terlutter, R., \& Capella, M. L. (2013). The gamification of advertising: Analysis and research directions of in-game advertising, advergames, and advertising in social network games. Journal of Advertising, 42(2-3), 95-112. https:// doi.org/10.1080/00913367.2013.7 74610

37. Tsang, M. M., Ho, S-.C., \& Liang, T-.P. (2004). Consumer attitudes toward mobile advertising: An empirical study. International Journal of Electronic Commerce, 8(3), 65-78. Retrieved from https:// www.researchgate.net/publication/228819052_Consumer_Attitudes_Toward_Mobile_Advertising_An_Empirical_Study

38. Usta, R. (2009). Üniversite orencilerinin mobil reklamciliga karsı tutumları. Dogus Üniversitesi Dergisi, 10(2), 294-309. Retrieved from http://journal.dogus.edu.tr/ index.php/duj/article/view/51

39. Wang, W. C. (2006). The effect of product knowledge and brand image on purchase intentions moderated by product category (Unpublished master thesis). Tatung University, Taiwan.

40. Wong, M. M. T., \& Tang, E. P. Y. (2008). Consumers' attitudes towards mobile advertising: The role of permission. Review of Business Research, 8(3), 181-187. Retrieved from https://citeseerx.ist. psu.edu/viewdoc/download?doi=10 .1.1.605.8682\&rep $=$ rep $1 \&$ type $=$ pdf

41. Yang, Y. T. (2009). A study of purchase intentions behavior to consumers on innovation technology smart phone in technology acceptance model and theory of reason action (Unpublished master thesis). Nan Hua University, Taiwan.

42. Zabadi, A., Shura, M., \& Elsayed, E. (2012). Consumer attitudes toward SMS advertising among Jordanian users. International Journal of Marketing Studies, 4(1), 77-94. http://dx.doi.org/10.5539/ ijms.v4n1p77

43. Zaichkowsky, J. L. (1985). Measuring the involvement construct. Journal of Consumer Research, 12, 341-352. https://doi. org/10.1086/208520 